Article

\title{
Synthesis, Spectroscopic, and Biological Studies of Mixed Ligand Complexes of Gemifloxacin and Glycine with Zn(II), Sn(II), and Ce(III)
}

\author{
Shimaa H. Sakr ${ }^{1,2}$, Hazem S. Elshafie ${ }^{2, *(\mathbb{D})}$, Ippolito Camele ${ }^{2}$ (1) and Sadeek A. Sadeek ${ }^{1}$ \\ 1 Department of Chemistry, Faculty of Science, Zagazig University, Zagazig 44519, Egypt; \\ shimaa.chemist@yahoo.com (S.H.S.); s_sadeek@zu.edu.eg (S.A.S.) \\ 2 School of Agricultural, Forestry, Food and Environmental Sciences, University of Basilicata, \\ Viale dell'Ateneo Lucano, 85100 Potenza, Italy; ippolito.camele@unibas.it \\ * Correspondence: hazem.elshafie@unibas.it; Tel.: +39-0971-205546; Fax: +39-0971-205503
}

Received: 30 April 2018; Accepted: 11 May 2018; Published: 15 May 2018

\begin{abstract}
Three novel mixed ligand metal complexes have been synthesized by the reaction of $\mathrm{Zn}(\mathrm{II}), \mathrm{Sn}(\mathrm{II})$, and Ce(III) with gemifloxacin (GMFX) in the presence of glycine (Gly) (1:1:1 molar ratio). The coordination possibility of the two ligands toward metal ions has been proposed in the light of elemental analysis, molar conductance, spectral infrared (IR), ultraviolet-visible (UV-Vis) and proton-nuclear magnetic resonance $\left({ }^{1} \mathrm{H}\right.$ NMR), and magnetic studies. Results suggest that GMFX and Gly interact with the metal ions as bidentate ligands. Electronic and magnetic data proposed the octahedral structure for all complexes under investigation. Antibacterial screening of the compounds was carried out in vitro against two Gram-positive bacteria, Clavibacter michiganensis and Bacillus megaterium, and two Gram-negative bacteria, Escherichia coli and Xanthomonas campestris. Antifungal activity was performed in vitro against Rhizoctonia solani, Sclerotinia sclerotiorum, Aspergillus niger, Botrytis cinerea, and Penicillium digitatum. The ligands and their complexes were also screened for their antioxidant activity. Results showed that some metal complexes showed more biological efficiency than the parent GMFX drug.
\end{abstract}

Keywords: gemifloxacin; proton-nuclear magnetic resonance; fungicidal; antibacterial; antioxidant activity

\section{Introduction}

Quinolones are a group of synthetic antibacterial agents used in treatment of many infections [1-3]. Fluoroquinolone gemifloxacin (GMFX) (Scheme 1A) is a synthetic broad-spectrum antibacterial agent [4] used in the treatment of acute bacterial exacerbation of chronic bronchitis and mild-to-moderate pneumonia. GMFX has excellent in vitro activity against both Gram-positive (G+ve) and Gram-negative $(\mathrm{G}-\mathrm{ve})$ organisms, including potent antibacterial activity against respiratory tract infection pathogens $[4,5]$. GMFX acts by inhibiting DNA synthesis through the inhibition of both DNA gyrase and topoisomerase IV, which are essential for bacterial growth. Fluoroquinolone antibiotics have also been found to have anti-inflammatory and anticancer effects. Recently, some experiments were carried out and revealed that GMFX has an anticancer effect on colon cancer via inhibition of metastasis [6]. The interaction of metal ions with diverse deprotonated fluoroquinolones has been thoroughly studied $[7,8]$. In many cases, the metal complexes of drugs are more active than the parent compound [8,9].

From this point of view, diverse metal complexes with fluoroquinolones have been synthesized in an attempt to investigate the physicochemical properties and evaluate their biological properties $[10,11]$ 
and potential antitumor activity in comparison with free fluoroquinolones [12-14]. Mixed ligand complexes play an important role in biological processes as exemplified by many instances in which enzymes are known to be activated by metal ions [11-17]. A good number of metal mixed-ligand complexes containing glycine (Gly) (Scheme 1B) with some other ligand are reported in the literature [18] where the Gly amino acid acts as bidentate ligand coordinating through the carboxylate oxygen and the amino nitrogen with octahedral geometry for metal chelates. The aim of the present work is to study the effect of changing atomic volume, atomic mass, and oxidation state of some metal ions ( $\mathrm{Zn}(\mathrm{II}), \mathrm{Sn}(\mathrm{II}), \mathrm{Ce}(\mathrm{III})$ ) with $\mathrm{Cl}^{-}$as counter ion on the biological activity of gemifloxacin as antibacterial agent in the presence of Gly and to examine the mode of coordination and the biological properties of the resulting complexes. The synthesized complexes were characterized physicochemically by melting point, molar conductivity, magnetic property, elemental, infrared (IR), ultraviolet-visible (UV-Vis) and proton-nuclear magnetic resonance ( ${ }^{1} \mathrm{H}$ NMR).

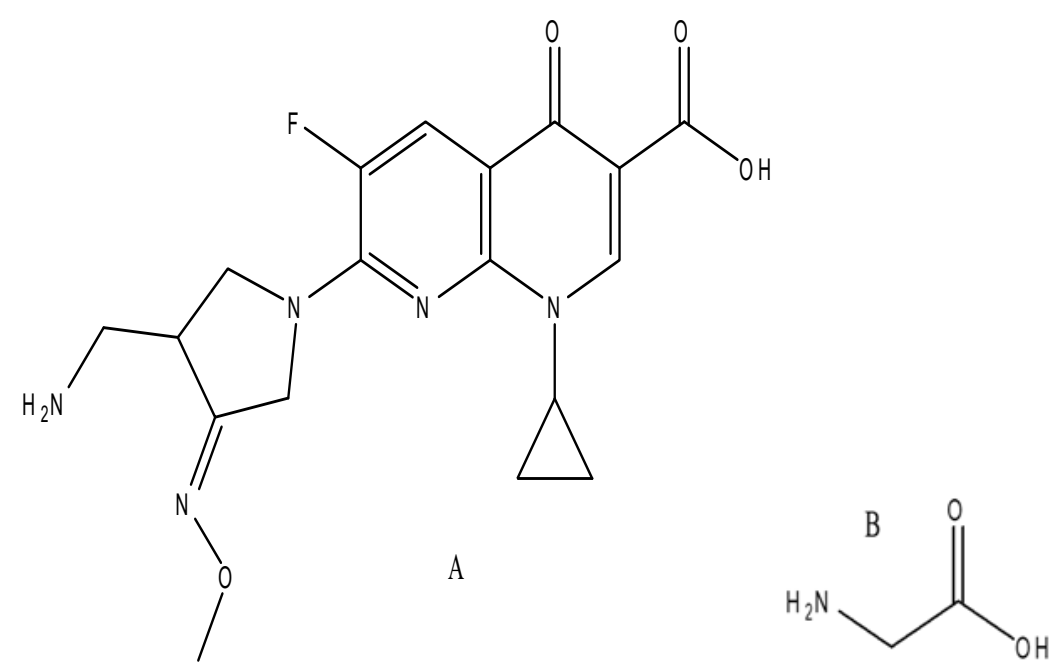

Scheme 1. (A). 7-[(4Z)-3-(Aminomethyl)-4-methoxyimino-pyrrolidin-1-yl]-1-cyclopropyl-6-fluoro4-oxo-1.8-naphthyridine-3-carboxylic acid (GMFX) and (B) amino acetic acid (Gly).

The biological characterization of GMFX and its synthesized metal complexes was carried out by an antifungal activity test activity against some phytopathogenic fungi such as; Rhizoctonia solani J.G. Kühn., Sclerotinia sclerotiorum (Lib.) de Bary., Aspergillus niger van Tieghem., Botrytis cinerea Pers., and Penicillium digitatum Sacc. On the other hand, the bactericidal effect of the above mentioned substances was performed against two G+ve bacteria Xanthomonas campestris Pammel and Bacillus megaterium de Bary and two G-ve bacteria Escherichia coli Migula and Clavibacter michiganensis Smith. In addition, antioxidant activity test has been also carried out for GMFX ligand and its synthesized metal complexes by using two different methods 2,2-diphenyl-1-picrylhydrazyl (DPPH) and 2,2'-azinobis (3-ethylbenzthiazoline-6-acid) (ABTS) for determine the radical scavenging activity (RSA\%).

\section{Results and Discussion}

GMFX reacts with $\mathrm{Zn}(\mathrm{II}), \mathrm{Sn}(\mathrm{II})$, and Ce(III) in the presence of Gly as secondary ligand at $100{ }^{\circ} \mathrm{C}$ in ethanol to form solid complexes. The complexes were obtained as colored powdered materials. Table 1 summarizes the carbon, hydrogen, and nitrogen elemental analysis as well as melting point, magnetic measurements, and molar conductance. Moreover, the synthesized complexes were characterized using elemental analysis, IR, UV-Vis and ${ }^{1} \mathrm{H}$ NMR spectra analyses. The molar ratio for all prepared complexes is GMFX:M:Gly = 1:1:1 which was established from the results of the chemical analyses and all the prepared complexes were air stable solids at room temperature. The IR spectroscopic data confirm the presence of water in the composition of the complexes [18] with the number of bound water molecules in these complexes being different. The structures of the complexes suggested from 
the elemental analysis agree quite well with their proposed formula. The metal ions are coordinated to a deprotonated carboxylate oxygen and pyridone oxygen of GMFX and Gly through the carboxylate oxygen and the amino nitrogen. Here, metal ions react with GMFX and Gly, forming complexes of monomeric structure where the metal ions are six coordinate and complete the coordination number with two water molecules (Scheme 2). The molar conductance values of the GMFX and their metal complexes in dimethyl formamide (DMF) with standard reference using $1 \times 10^{-3} \mathrm{~mol}^{-1}$ solutions at room temperature were found to be in the range from 47.50 to $150.11 \mathrm{~S} \mathrm{~cm}^{2} \mathrm{~mol}^{-1}$. The data indicated that the complexes are electrolytes and the chloride ions were found as counter ions at all three complexes $[19,20]$. For our complexes, in order to verify that the chloride is ionic, their solutions were tested with aqueous solutions of $\mathrm{AgNO}_{3}$. A white precipitate was formed which indicated the presence of $\mathrm{Cl}^{-}$as counter ions. The magnetic moments (as B. M.) of the complexes were measured at room temperature. The $\mathrm{Zn}$ (II) and $\mathrm{Sn}$ (II) complexes were found to be of diamagnetic character with octahedral molecular geometry but the complex of $\mathrm{Ce}(\mathrm{III})$ is susceptible and their magnetic moments were $2.34 \mu_{\text {eff. }}$.

Table 1. Elemental analysis and physico-analytical data for gemifloxacin (GMFX), glycine (Gly), and its metal complexes.

\begin{tabular}{|c|c|c|c|c|c|c|c|c|c|c|}
\hline Compounds M.wt. and M.F. & Yield \% & $\mathrm{Mp} /{ }^{\circ} \mathrm{C}$ & Color & \multicolumn{5}{|c|}{ Found (Calcd.) (\%) } & $\begin{array}{c}\mu_{\mathrm{eff}} \\
\text { (B. M.) }\end{array}$ & $\underset{\mathrm{mol}^{-1}}{\Lambda \mathrm{S} \mathrm{cm}^{2}}$ \\
\hline GMFX $389.4\left(\mathrm{C}_{18} \mathrm{H}_{20} \mathrm{FN}_{5} \mathrm{O}_{4}\right)$ & - & 220 & $\begin{array}{l}\text { White } \\
\text { brown }\end{array}$ & $\begin{array}{l}55.50 \\
(55.52)\end{array}$ & $\begin{array}{c}5.18 \\
(5.17)\end{array}$ & $\begin{array}{l}17.98 \\
(17.99)\end{array}$ & - & - & - & 47.50 \\
\hline Gly $75.07\left(\mathrm{C}_{2} \mathrm{H}_{5} \mathrm{NO}_{2}\right)$ & - & 233 & White & $\begin{array}{l}31.98 \\
(32.00)\end{array}$ & $\begin{array}{c}6.64 \\
(6.66)\end{array}$ & $\begin{array}{l}18.63 \\
(18.66)\end{array}$ & - & - & - & 50.77 \\
\hline (1) $619.89\left(\mathrm{ZnC}_{20} \mathrm{H}_{31} \mathrm{~N}_{6} \mathrm{O}_{9} \mathrm{FCl}\right)$ & 78 & 310 & $\begin{array}{c}\text { Faint } \\
\text { yellow }\end{array}$ & $\begin{array}{l}38.69 \\
(38.71)\end{array}$ & $\begin{array}{c}4.97 \\
(5.00)\end{array}$ & $\begin{array}{l}13.49 \\
(13.55)\end{array}$ & $\begin{array}{l}10.50 \\
(10.55)\end{array}$ & $\begin{array}{c}5.72 \\
(5.72)\end{array}$ & - & 97.58 \\
\hline (2) $655.20\left(\mathrm{SnC}_{20} \mathrm{H}_{29} \mathrm{~N}_{6} \mathrm{O}_{8} \mathrm{FCl}\right)$ & 82 & 330 & $\begin{array}{c}\text { Faint } \\
\text { brown }\end{array}$ & $\begin{array}{l}36.60 \\
(36.63)\end{array}$ & $\begin{array}{c}4.39 \\
(4.42)\end{array}$ & $\begin{array}{l}12.79 \\
(12.82)\end{array}$ & $\begin{array}{l}17.98 \\
(18.11)\end{array}$ & $\begin{array}{c}5.38 \\
(5.41)\end{array}$ & - & 86.34 \\
\hline (3) $730.10\left(\mathrm{CeC}_{20} \mathrm{H}_{31} \mathrm{~N}_{6} \mathrm{O}_{9} \mathrm{FCl}_{2}\right)$ & 95 & 340 & Beige & $\begin{array}{l}32.82 \\
(32.87)\end{array}$ & $\begin{array}{c}4.18 \\
(4.24)\end{array}$ & $\begin{array}{l}11.42 \\
(11.50)\end{array}$ & $\begin{array}{l}19.12 \\
(19.19)\end{array}$ & $\begin{array}{c}9.70 \\
(9.72)\end{array}$ & 2.34 & 150.11 \\
\hline
\end{tabular}

Where: M.wt.: molecular weight; M.F.: molecular formula; Mp: melting point; Calcd.: calculated values; $\mu_{\text {eff }}$ : effective magnetic moment; S: siemens $\left(\mathrm{Ohm}^{-1}\right)$.

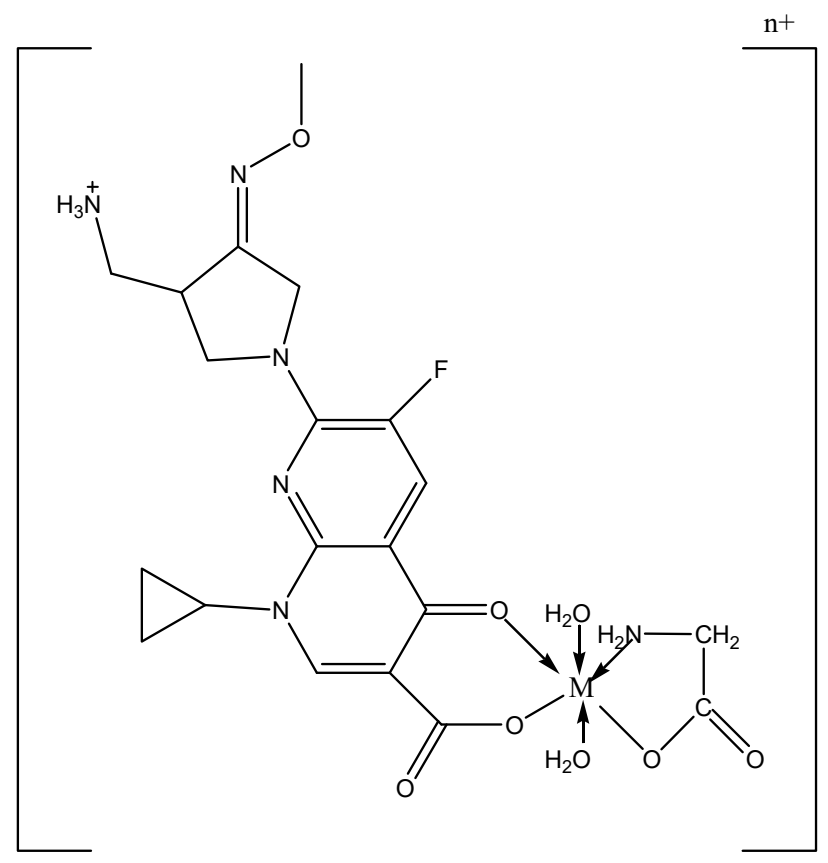

Scheme 2. The coordination mode of $\mathrm{Zn}(\mathrm{II}), \mathrm{Sn}(\mathrm{II})$, and Ce(III) with mixed ligands. $\mathrm{M}=\mathrm{Zn}(\mathrm{II}), \mathrm{Sn}(\mathrm{II})$, and $\mathrm{Ce}(\mathrm{III}) . n=1$ for $\mathrm{Zn}(\mathrm{II}), \mathrm{Sn}(\mathrm{II}) . n=2$ for $\mathrm{Ce}(\mathrm{III})$. 
The chloride content in the complexes was determined by using two methods; Mohr and Volhard. The lattice water for the three complexes was determined by heating an accurate weight of each complex from the ambient temperature up to $\sim 120{ }^{\circ} \mathrm{C}$, the weight loss for each chelate were calculated. The weight loss of $\mathrm{Sn}$ (II) and Ce(III) complexes are $2.74 \%$, and $2.46 \%$, respectively. These data support the proposed complexes' chemical formulae and indicate the presence of one hydration water molecule for $\mathrm{Sn}(\mathrm{II})$ and $\mathrm{Ce}(\mathrm{III})$ complexes.

On the other hand, the measurement of the molar conductivity showed clear differences between the three prepared complexes (divalent and trivalent salt ions) as we have already specified in the manuscript (Table 1). Based on the above explanation, there is a steady relationship between increasing the conductivity of the compound and its solubility, as has been discussed by Uivarosi [21] who reported that the quinolone chelates of trivalent cations have shown an improved solubility compared to that of the free ligand and this behavior could be advantageous for pharmaceutical formulation.

\subsection{Infrared Absorption Spectra}

The infrared spectra of Zn(II), Sn(II), and Ce(III) complexes and free GMFX, Gly were measured as potassium bromide $(\mathrm{KBr})$ discs. These spectra are shown in Figure 1 and the assignments are given in Table 2. The infrared spectra of the three complexes were compared with those of the free ligands in order to determine the site of coordination that may be involved in the chelation process. These peaks were expected to be involved in chelation. The position or the intensities of these peaks were expected to be changed upon complexation. The IR spectra of the complexes were very similar due to the same atoms of GMFX and Gly involved in the bonding to the metal. In most cases, the proposed mechanism of the interaction between GMFX and the metal cations was chelation between the metal ions through pyridone and carboxylic groups; therefore, it was important to give more attention to these group vibrations. The infrared spectra of the metal complexes exhibit a broad band between 3455 and $3411 \mathrm{~cm}^{-1}$ which corresponds to the $v(\mathrm{O}-\mathrm{H})$ vibration and confirms the presence of water molecules in all complexes [18,22]. The two bands observed at 1720 and $1632 \mathrm{~cm}^{-1}$ in the spectrum of the free GMFX have been assigned to the stretching vibration of carboxylic $v(\mathrm{COOH})$ and the pyridone group $v(C=O)$, respectively [23], and at $1703 \mathrm{~cm}^{-1}$ for $v(C=O)$ carboxyl of Gly [24-27].

In the IR spectra of the complexes, the band corresponding to the carboxylic group appears with $\Delta v=v_{\text {as }}\left(\mathrm{COO}^{-}\right)-v_{\mathrm{s}}\left(\mathrm{COO}^{-}\right)>200 \mathrm{~cm}^{-1}$, indicating carboxylic group involvement in monodentate coordination [28,29]. These changes in the IR spectra suggest that GMFX is bound to metal ions via the carboxylate oxygen atom [23]. Also, the second important band at $1634 \mathrm{~cm}^{-1}$, being attributed to the pyridone group, shifted to lower values at $1575 \mathrm{~cm}^{-1}$ for $\mathrm{Sn}$ (II), $1557 \mathrm{~cm}^{-1}$ for $\mathrm{Zn}$ (II), and $1559 \mathrm{~cm}^{-1}$ for Ce(III) being a good indication that this group is coordinated to the metal ions [30,31].

Regarding chelation through amino acids, the IR spectra exhibit significant features in the $\mathrm{vNH}_{2}$ and $v \mathrm{COO}^{-}$regions. It is worthwhile to mention here that free amino acids exist as zwitterions and the IR spectra of these cannot be compared entirely with those of metal complexes as amino acids in metal complexes do not exist as zwitterions. Free amino acids with $\mathrm{NH}_{3}$ functions in particular show $v \mathrm{NH}_{3}$ in the range of $3130-3030 \mathrm{~cm}^{-1}$. In the complexes, $\mathrm{NH}_{3}$ gets deprotonated and binds to metal through the neutral $\mathrm{NH}_{2}$ group. The transformation of $\mathrm{NH}_{3}$ to $\mathrm{NH}_{2}$ must result in an upward shift in the $v \mathrm{NH}_{2}$ of free amino acids. At the isoelectric point, they must show $v \mathrm{NH}_{2}$ in the region $3500-3300 \mathrm{~cm}^{-1}$ [26]. In the present complexes, the IR spectra showed characteristic bands in the region of $3459-3181 \mathrm{~cm}^{-1}$, which are lower compared to those of free $\mathrm{vNH}_{2}$. Hence, it can be concluded that the nitrogen of the amino group is involved in coordination. The IR spectra show strong evidence in support of the involvement of the carboxylate group in coordination.

In comparison with free amino acids, the $v \mathrm{COO}^{-}$(asymmetric) and $\nu \mathrm{COO}^{-}$(symmetric) record different shifts, which confirms the monodenticity [32] of the carboxylate group. The values of band shift $\Delta v=v_{\text {as }}\left(\mathrm{COO}^{-}\right)-v_{\mathrm{s}}\left(\mathrm{COO}^{-}\right)$have indicated that the carboxylate group in Gly was chelated in a uni-negatively manner to the metal ions. 
The spectra of the isolated solid complexes show a group of new bands with different intensities, being characteristic for $v(\mathrm{M}-\mathrm{O})$ and $v(\mathrm{M}-\mathrm{N})$. The $v(\mathrm{M}-\mathrm{O})$ and $v(\mathrm{M}-\mathrm{N})$ bands were observed at 689 and $601 \mathrm{~cm}^{-1}$ for $\mathrm{Sn}(\mathrm{II})$, at 692 and $642 \mathrm{~cm}^{-1}$ for $\mathrm{Zn}(\mathrm{II})$, at 693, 669, 640, 613, and $590 \mathrm{~cm}^{-1}$ for Ce(III), and being absent from the spectra of GMFX and Gly. This indicates coordination of GMFX and Gly through the pyridone, the carboxylate oxygen of GMFX, Gly, and the amino nitrogen of Gly.

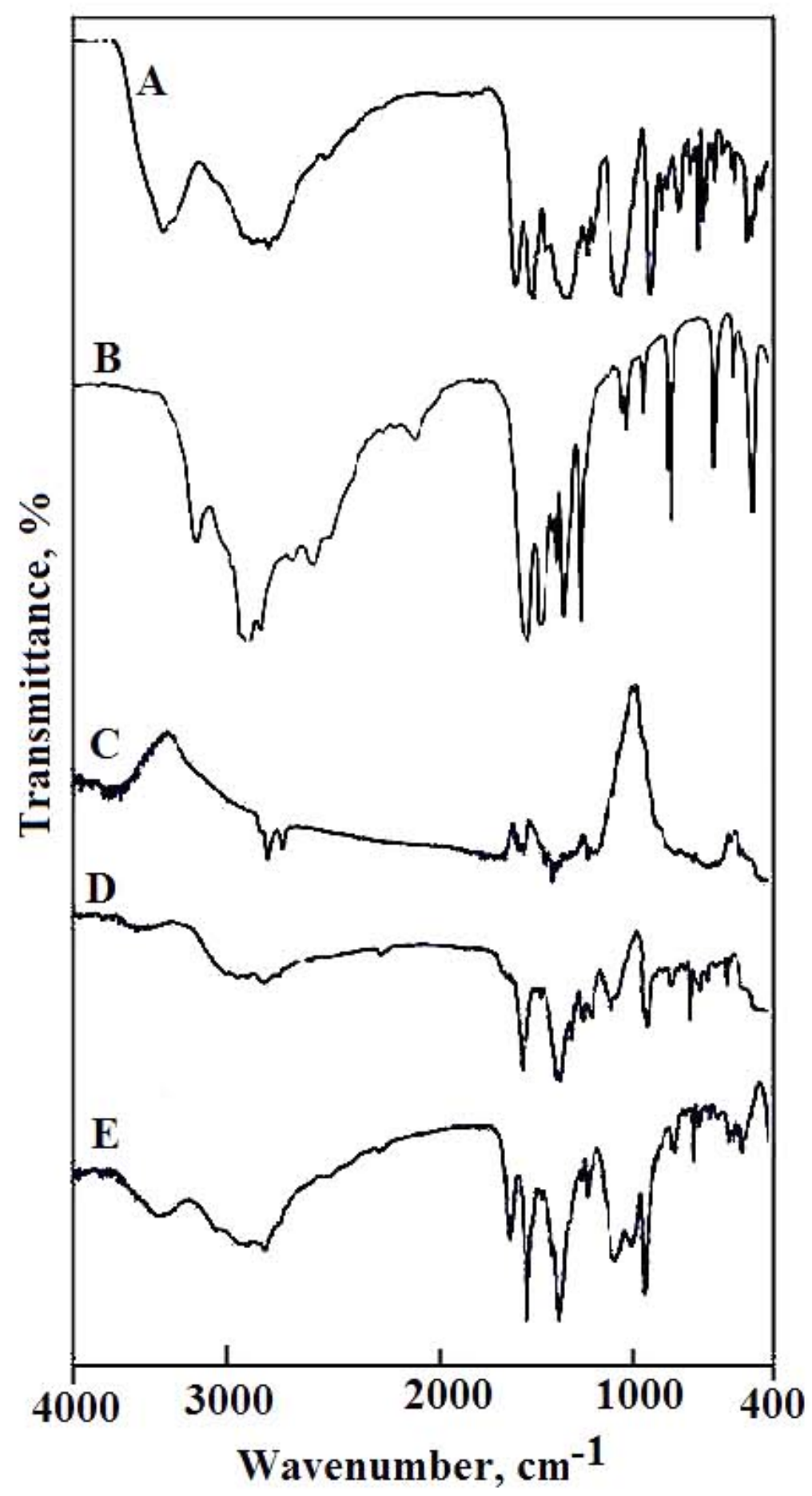

Figure 1. Infrared (IR) spectra for (A) gemifloxacin (GMFX), (B) glycine (Gly), (C) Sn(II), (D) Zn(II), and (E) Ce(III). 
Table 2. Infrared frequencies $\left(\mathrm{cm}^{-1}\right)$ and tentative assignments for (A) GMFX, (B) Gly, (C) Sn(II), (D) $\mathrm{Zn}(\mathrm{II})$, and (E) Ce(III).

\begin{tabular}{|c|c|c|c|c|c|}
\hline A & B & $\mathrm{C}$ & $\mathbf{D}$ & E & Assignments \\
\hline $3533 w$ & $\begin{array}{l}3522 w \\
3478 w\end{array}$ & $3341 \mathrm{mbr}$ & $3545 w$ & $3375 \mathrm{mbr}$ & $v(\mathrm{O}-\mathrm{H}) ; \mathrm{H}_{2} \mathrm{O} ; \mathrm{COOH}$ \\
\hline $\begin{array}{l}3156 w \\
3044 w\end{array}$ & $3133 v w$ & $\begin{array}{l}3067 \mathrm{vw} \\
3009 \mathrm{~m}\end{array}$ & 3044sh & $\begin{array}{c}3089 v w \\
3022 w\end{array}$ & $v(\mathrm{~N}-\mathrm{H})$ \\
\hline $\begin{array}{c}2943 \mathrm{~s} \\
2867 \mathrm{vw} \\
2778 \mathrm{~m} \\
2712 \mathrm{~ms}\end{array}$ & $\begin{array}{l}2955 \mathrm{~m} \\
2843 \mathrm{~m} \\
2767 \mathrm{w} \\
2722 \mathrm{w} \\
2712 \mathrm{~m}\end{array}$ & $\begin{array}{c}2889 w \\
2766 w \\
2711 v w\end{array}$ & $\begin{array}{c}2974 \mathrm{~m} \\
2871 \mathrm{vw} \\
2800 \mathrm{~m} \\
2758 \mathrm{w}\end{array}$ & $\begin{array}{c}2955 \mathrm{~m} \\
2822 \mathrm{vw} \\
2756 \mathrm{w} \\
2716 \mathrm{~m}\end{array}$ & $v(\mathrm{C}-\mathrm{H}) ;$ aliphatic \\
\hline $1732 v s$ & 1703vs & - & - & - & $v(\mathrm{C}=\mathrm{O}) ; \mathrm{COOH}$ \\
\hline- & $1620 v s$ & $1620 \mathrm{vs}$ & $1622 \mathrm{~m}$ & $1624 \mathrm{~s}$ & $v_{\mathrm{as}}\left(\mathrm{COO}^{-}\right)$ \\
\hline $1624 v s$ & $\begin{array}{l}1589 \mathrm{~s} \\
1539 \mathrm{~m}\end{array}$ & $1574 \mathrm{~s}$ & $1574 s$ & $1570 v s$ & $v(\mathrm{C}=\mathrm{N})$ \\
\hline 1466vs & $\begin{array}{l}1494 \mathrm{~s} \\
1474 \mathrm{~s}\end{array}$ & $1485 v s$ & $1462 \mathrm{vs}$ & $1485 s$ & - $\mathrm{CH}$; deformations of $\mathrm{CH}_{2}$ \\
\hline $\begin{array}{l}1385 \mathrm{~m} \\
1367 \mathrm{sh}\end{array}$ & $1377 \mathrm{~s}$ & $\begin{array}{c}1393 s \\
1378 w\end{array}$ & $\begin{array}{l}1385 v s \\
1350 \mathrm{sh}\end{array}$ & $1393 s$ & $v_{\mathrm{s}}\left(\mathrm{COO}^{-}\right)$ \\
\hline $1331 \mathrm{~ms}$ & $1322 \mathrm{~m}$ & $1304 \mathrm{~ms}$ & $1300 \mathrm{~m}$ & $1308 s$ & $\delta_{\mathrm{b}}\left(-\mathrm{CH}_{2}\right)$ \\
\hline $\begin{array}{l}1261 \mathrm{vs} \\
1223 \mathrm{w} \\
1188 \mathrm{~m} \\
1156 \mathrm{~m}\end{array}$ & $\begin{array}{c}1285 \mathrm{~s} \\
1211 \mathrm{sh} \\
1172 \mathrm{vw} \\
1146 \mathrm{~ms}\end{array}$ & $\begin{array}{c}1269 \mathrm{~s} \\
1189 \mathrm{vw} \\
1144 \mathrm{w}\end{array}$ & $\begin{array}{l}1269 \mathrm{~s} \\
1184 \mathrm{~m} \\
1146 \mathrm{~m}\end{array}$ & $\begin{array}{l}1265 \mathrm{~s} \\
1184 \mathrm{~m} \\
1146 \mathrm{~m}\end{array}$ & $v(\mathrm{C}-\mathrm{O}), v(\mathrm{C}-\mathrm{N})$ and $v(\mathrm{C}-\mathrm{C})$ \\
\hline $\begin{array}{l}1089 \mathrm{~m} \\
1034 \mathrm{~s}\end{array}$ & $1034 \mathrm{~s}$ & $\begin{array}{l}1103 \mathrm{~m} \\
1072 \mathrm{sh} \\
1038 \mathrm{~m}\end{array}$ & $1038 \mathrm{~ms}$ & $\begin{array}{l}1107 \mathrm{~m} \\
1034 \mathrm{~s}\end{array}$ & $\delta_{\mathrm{r}}\left(-\mathrm{CH}_{2}\right)$ \\
\hline $\begin{array}{l}989 \mathrm{vw} \\
968 \mathrm{~m} \\
933 \mathrm{~m} \\
887 \mathrm{~ms} \\
833 \mathrm{~ms} \\
822 \mathrm{vw}\end{array}$ & $\begin{array}{c}989 w \\
937 \mathrm{~ms} \\
894 \mathrm{w} \\
867 \mathrm{~m} \\
833 \mathrm{~ms}\end{array}$ & $\begin{array}{l}989 \mathrm{vw} \\
941 \mathrm{~ms} \\
911 \mathrm{vw} \\
829 \mathrm{~m}\end{array}$ & $\begin{array}{l}945 \mathrm{~ms} \\
899 \mathrm{~m} \\
844 \mathrm{~m} \\
822 \mathrm{w} \\
800 \mathrm{vw}\end{array}$ & $\begin{array}{c}945 \mathrm{~s} \\
895 \mathrm{~m} \\
829 \mathrm{~m}\end{array}$ & -CH-bend; phenyl \\
\hline $\begin{array}{c}795 \mathrm{~m} \\
767 \mathrm{vw} \\
748 \mathrm{~m} \\
710 \mathrm{~m}\end{array}$ & $\begin{array}{l}783 \mathrm{~m} \\
721 \mathrm{~s}\end{array}$ & $\begin{array}{l}779 \mathrm{~m} \\
745 \mathrm{~s} \\
710 \mathrm{w}\end{array}$ & $\begin{array}{l}778 \mathrm{w} \\
752 \mathrm{~m} \\
711 \mathrm{~m}\end{array}$ & $\begin{array}{l}778 \mathrm{~m} \\
748 \mathrm{~s} \\
710 \mathrm{~m}\end{array}$ & $\delta_{\mathrm{b}}\left(\mathrm{COO}^{-}\right)$ \\
\hline $\begin{array}{c}656 \mathrm{w} \\
622 \mathrm{~m} \\
571 \mathrm{~ms} \\
550 \mathrm{vw} \\
486 \mathrm{~m} \\
478 \mathrm{vw} \\
436 \mathrm{~s}\end{array}$ & $\begin{array}{l}644 \mathrm{vw} \\
621 \mathrm{~ms} \\
559 \mathrm{~s} \\
494 \mathrm{~ms} \\
436 \mathrm{~m} \\
406 \mathrm{~m}\end{array}$ & $\begin{array}{l}625 \mathrm{~ms} \\
578 \mathrm{~m} \\
544 \mathrm{w} \\
502 \mathrm{~m} \\
478 \mathrm{w} \\
433 \mathrm{w} \\
413 \mathrm{w}\end{array}$ & $\begin{array}{c}633 \mathrm{~ms} \\
583 \mathrm{~m} \\
544 \mathrm{w} \\
505 \mathrm{~s} \\
478 \mathrm{sh} \\
444 \mathrm{vw} \\
422 \mathrm{w}\end{array}$ & $\begin{array}{l}667 \mathrm{vw} \\
629 \mathrm{~m} \\
578 \mathrm{w} \\
544 \mathrm{~m} \\
502 \mathrm{~m} \\
478 \mathrm{sh} \\
440 \mathrm{w}\end{array}$ & $\begin{array}{l}v(\mathrm{M}-\mathrm{O}) . v(\mathrm{M}-\mathrm{N}) \text { and ring } \\
\text { deformation }\end{array}$ \\
\hline
\end{tabular}

Keys: $\mathrm{s}=$ strong, $\mathrm{w}=$ weak, $\mathrm{v}=$ very, $\mathrm{m}=$ medium $, \mathrm{br}=\mathrm{broad}, \mathrm{sh}=$ shoulder, $\mathrm{v}=$ stretching,$\delta \mathrm{b}=$ bending.

\subsection{Ultraviolet-Visible Spectroscopy Analysis}

Application of ultraviolet spectroscopy can be useful for structural determination of chelates since they all absorb in this region $[24,33,34]$. Formation of mixed ligand complexes was confirmed by the electronic absorption spectra. The electronic absorption spectra of the ligand along with the $\mathrm{Zn}(\mathrm{II})$, 
Sn(II), and Ce(III) complexes from 200 to $800 \mathrm{~nm}$ are shown in (Figure 2). Free GMFX showed bands at $213-245 \mathrm{~nm}$ and $276-343 \mathrm{~nm}$ which may be assigned to $\pi-\pi^{*}$ and $n-\pi^{*}$ transitions. Respectively. The shift of the absorption bands to higher or lower values and the appearance of new bands for the complexes are attributed to the mixed ligand complexation.
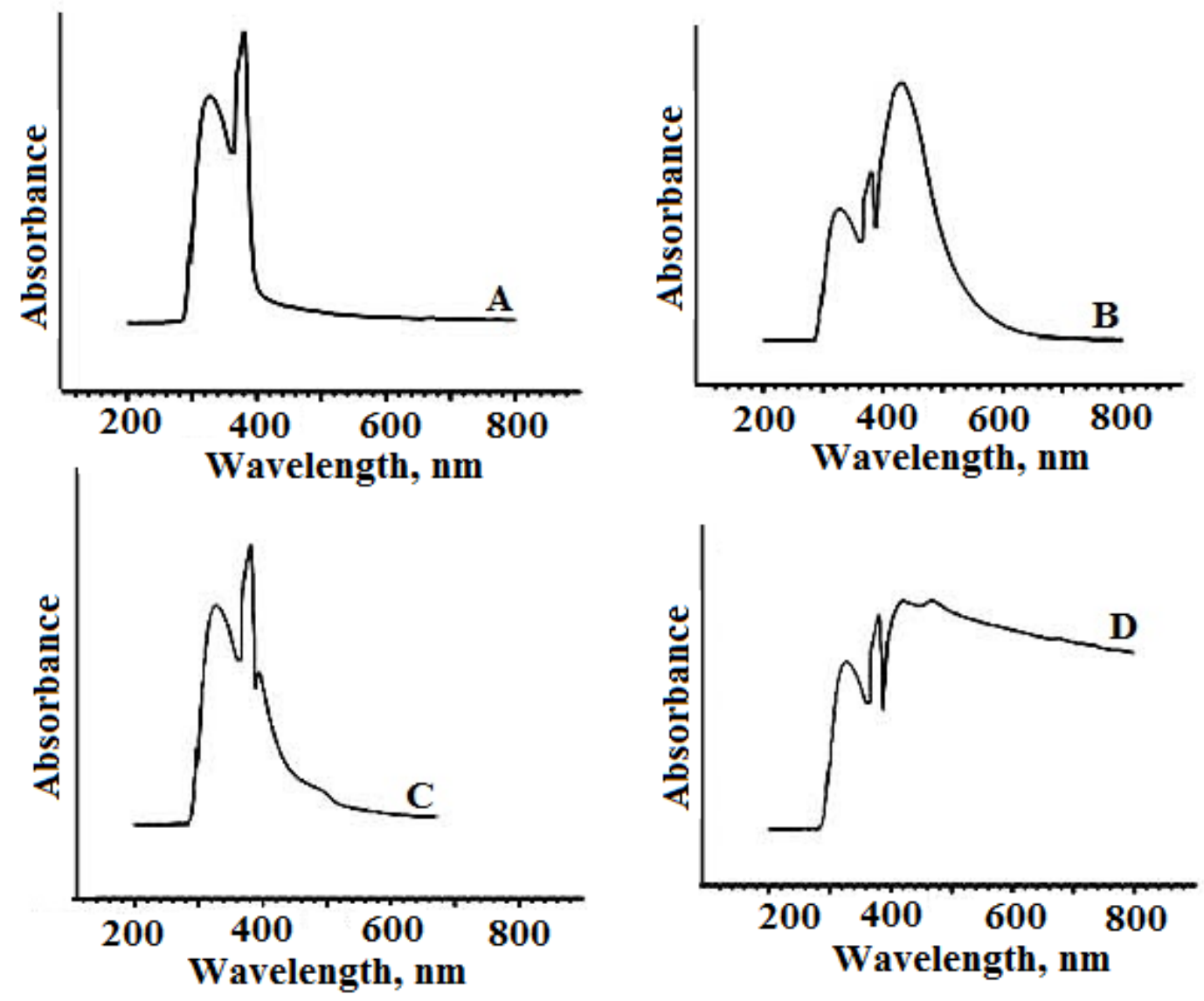

Figure 2. Ultraviolet-visible (UV-Vis). Spectrum for (A) GMFX, (B) Sn(II), (C) Zn(II), and (D) Ce(III).

The decrease or increase of the absorption bands and the appearance of new bands upon coordination could be caused by the following effects: (1) the expected increase of the metal ion mass upon coordination; (2) the increase of the electron density on the metal ions by ligand, and (3) the decrease of the electron density on oxygen and nitrogen donor atoms. The complexes of $\mathrm{Zn}$ (II), Sn(II), and $\mathrm{Ce}(\mathrm{III})$ showed bands in the range of $402-468 \mathrm{~nm}$, which may be assigned to ligand-metal charge transfer (Table 3).

Table 3. UV-Vis spectral data of the free ligand GMFX and its metal complexes.

\begin{tabular}{ccccc}
\hline \multirow{2}{*}{ Assignments (nm) } & \multirow{2}{*}{ GMFX } & \multicolumn{3}{c}{ GMFX Metal Complexes } \\
\cline { 3 - 5 } & & Zn(II) & Sn(II) & Ce(III) \\
\hline $\boldsymbol{\pi}-\boldsymbol{\pi}^{*}$ transitions & 326 & 332 & 330 & 332 \\
$\boldsymbol{n}-\boldsymbol{\pi}^{*}$ transitions & 380 & 390 & 388 & 392 \\
Ligand-metal charge transfer & - & 402 & 432 & 420,468 \\
\hline
\end{tabular}

\subsection{Proton-Nuclear Magnetic Resonance Spectra Analysis}

The suggested molecular structures of the complexes were also proved by nuclear magnetic resonance (NMR) spectroscopy. The ${ }^{1} \mathrm{H}$ NMR spectra of the ligands and their metal complexes in 
$\mathrm{CD}_{3} \mathrm{OD}$ displayed distinct signals with appropriate multiplets; the signal assignments are shown in (Figure 3). The ${ }^{1} \mathrm{H}$ NMR spectrum obtained for GMFX shows peaks in the range $\delta=8.02-8.72 \mathrm{ppm}$ for the protons of an aromatic ring, a multiplet at $\delta=1.14-1.33 \mathrm{ppm}$ corresponding to $-\mathrm{CH}_{2}$ and $-\mathrm{CH}$ cyclopropane group, between 3.32 and $3.36 \mathrm{ppm}$ for a $-\mathrm{CH}_{2}$ aliphatic group, and a singlet peak at $\delta=11.0 \mathrm{ppm}$ for the proton of carboxylic acid. The ${ }^{1} \mathrm{H}$ NMR spectrum of glycine shows a peak at $\delta=11.0 \mathrm{ppm}$ for the proton of carboxylic acid and a peak at $\delta=2.0 \mathrm{ppm}$ for the amine (Table 4).

Comparing the main signals of the complexes with those of GMFX and Gly, the ${ }^{1} \mathrm{H}$ NMR spectra of the complexes showed chemical shift values that were only slightly changed compared with the free ligands, except for the carboxylic acid proton signal: the resonance of the carboxylic proton $(\mathrm{COOH})$ was not detected in the spectra of the three complexes, suggesting coordination of GMFX and Gly through its carboxylation to oxygen atoms $[24,25]$. Also, the ${ }^{1} \mathrm{H}$ NMR spectra for the complexes exhibit a new peak in the range of 4.50-4.89 ppm, due to the presence of water molecules in the complexes [35].
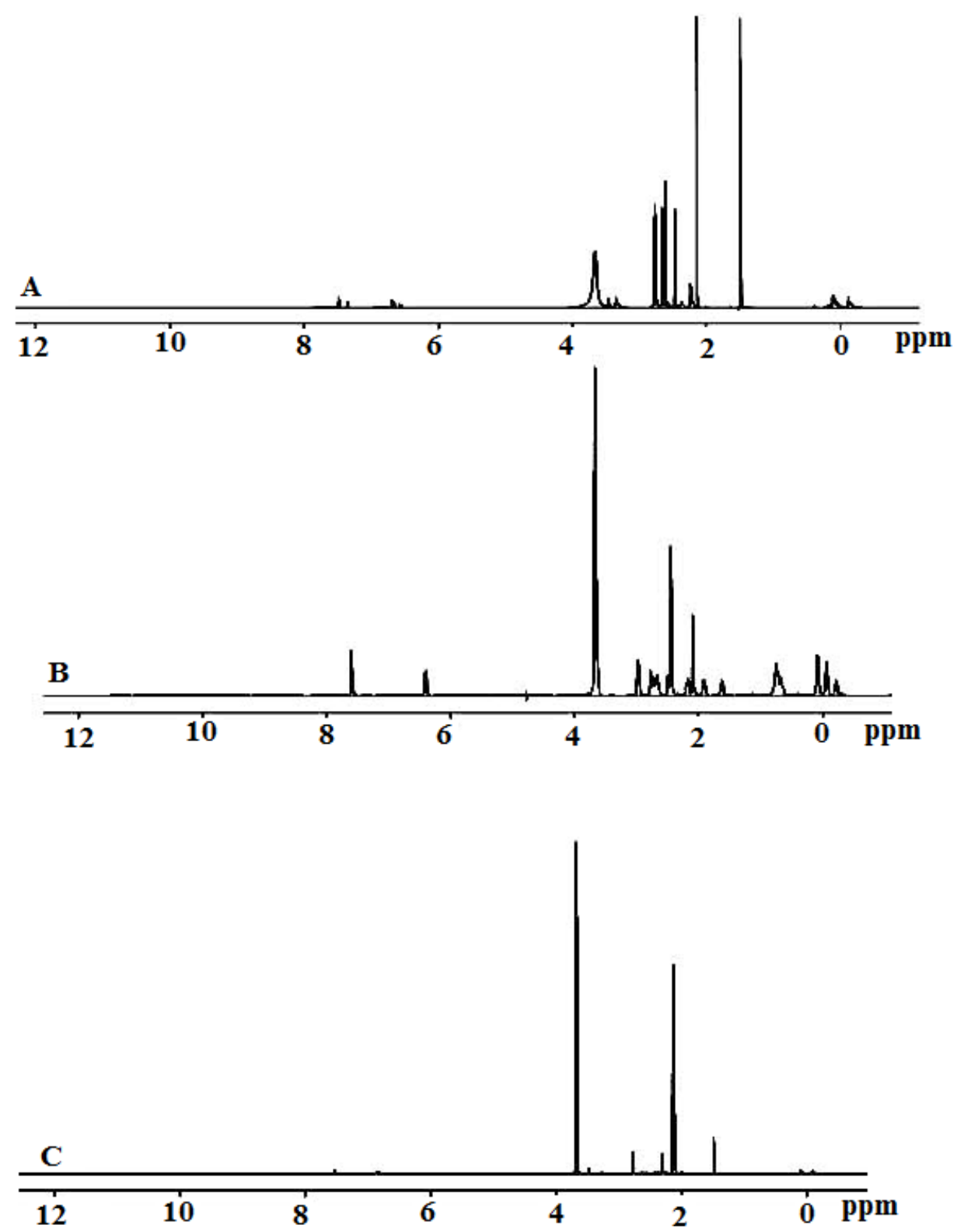

Figure 3. Proton-nuclear magnetic resonance $\left({ }^{1} \mathrm{H}\right.$ NMR) spectra for (A) $[\mathrm{Sn}(\mathrm{GMFX})(\mathrm{Gly})] \mathrm{Cl}_{2}$, (B) $[\mathrm{Zn}(\mathrm{GMFX})(\mathrm{Gly})] \mathrm{Cl}_{2} \cdot \mathrm{H}_{2} \mathrm{O}$, and (C) $[\mathrm{Ce}(\mathrm{GMFX})(\mathrm{Gly})] \mathrm{SO}_{4} \cdot \mathrm{H}_{2} \mathrm{O}$. 
Table 4. ${ }^{1} \mathrm{H}$ NMR values (ppm) and tentative assignments for GMFX, Gly ligands and its metal complexes.

\begin{tabular}{cccccc}
\hline GMFX & Gly & Zn(II) & Sn(II) & Ce(III) & Assignments \\
\hline $1.14-1.33$ & - & $1.29-1.32$ & $1.20-1.33$ & $1.14-1.33$ & $\delta \mathrm{H} .-\mathrm{CH}_{2}$ and $-\mathrm{CH}$ cyclopropane \\
2.71 & 2.00 & 2.71 & 2.72 & 2.71 & $\delta \mathrm{H}_{-}{ }^{+} \mathrm{NH}_{2}$ \\
$3.32-3.36$ & $3.59-$ & $3.32-3.844 .59$ & $3.36-3.994 .89$ & $3.21-3.994 .50$ & $\delta \mathrm{H} .-\mathrm{CH}_{2}$ aliphatic $\delta \mathrm{H}_{2} \mathrm{O} \mathrm{H}_{2}$ \\
$8.02-8.72$ & - & $8.40-8.71$ & $8.40-8.71$ & $8.40-8.71$ & $\delta \mathrm{H}_{-}-\mathrm{CH}$ aromatic \\
11 & 11 & - & - & - & $\delta \mathrm{H} .-\mathrm{COOH}$ \\
\hline
\end{tabular}

\subsection{Biological Activities}

\subsubsection{Antibacterial Activity}

The results of antibacterial test showed that the tested ligands and its metal complexes were able to inhibit the growth of all studied bacterial strains in a dose dependent manner (Table 5). In particular, all GMFX-metal complexes demonstrated the highest significant activity against E. coli at 10,000 ppm compared to all other treatments. Whereas, GMFX 10,000 ppm and its Sn and Zn complexes at 1000 ppm showed moderate activity. In contrast. GMFX at 1000 and 100 ppm and its metals complexes at 100 ppm showed the lowest significant activity against E. coli.

Table 5. Antibacterial activity of the studied GMFX ligand and its metal complexes compared to four synthetic antibiotics.

\begin{tabular}{ccccc}
\hline \multicolumn{5}{c}{ Bacterial Growth Inhibition \% } \\
\hline \multicolumn{2}{c}{ G-ve } & \multicolumn{2}{c}{ G+ve } \\
\hline Treatments $\mu \mathrm{g} / \mathrm{mL}$ & E. coli & X. campestris & C. michiganensis & B. megaterium \\
\hline GMFX 10,000 & $68.9 \pm 0.1 \mathrm{~b}$ & $75.6 \pm 0.1 \mathrm{ab}$ & $90.0 \pm 0.9 \mathrm{ab}$ & $54.4 \pm 0.2 \mathrm{bc}$ \\
GMFX 1000 & $61.1 \pm 0.2 \mathrm{bc}$ & $57.8 \pm 0.3 \mathrm{bc}$ & $86.0 \pm 0.4 \mathrm{~b}$ & $43.3 \pm 0.1 \mathrm{c}$ \\
GMFX 100 & $55.5 \pm 0.6 \mathrm{c}$ & $50.0 \pm 0.2 \mathrm{c}$ & $85.0 \pm 0.6 \mathrm{~b}$ & $37.8 \pm 0.1 \mathrm{~cd}$ \\
Sn-GMFX 10,000 & $82.2 \pm 0.3 \mathrm{a}$ & $82.2 \pm 0.2 \mathrm{a}$ & $97.0 \pm 0.7 \mathrm{a}$ & $56.7 \pm 0.1 \mathrm{bc}$ \\
Sn-GMFX 1000 & $65.6 \pm 0.2 \mathrm{~b}$ & $62.2 \pm 0.2 \mathrm{bc}$ & $86.0 \pm 0.5 \mathrm{~b}$ & $44.4 \pm 0.1 \mathrm{c}$ \\
Sn-GMFX 100 & $52.2 \pm 0.1 \mathrm{c}$ & $52.2 \pm 0.1 \mathrm{c}$ & $84.0 \pm 0.6 \mathrm{~b}$ & $38.9 \pm 0.2 \mathrm{~cd}$ \\
Zn-GMFX 10,000 & $80.0 \pm 0.1 \mathrm{a}$ & $83.3 \pm 0.2 \mathrm{a}$ & $95.0 \pm 0.8 \mathrm{a}$ & $57.8 \pm 0.2 \mathrm{bc}$ \\
Zn-GMFX 1000 & $65.6 \pm 0.1 \mathrm{~b}$ & $60.0 \pm 0.2 \mathrm{bc}$ & $89.0 \pm 0.6 \mathrm{ab}$ & $48.9 \pm 0.2 \mathrm{c}$ \\
Zn-GMFX 100 & $52.0 \pm 0.4 \mathrm{c}$ & $51.1 \pm 0.2 \mathrm{c}$ & $85.0 \pm 0.4 \mathrm{~b}$ & $37.8 \pm 0.3 \mathrm{~cd}$ \\
Ce-GMFX 10,000 & $83.0 \pm 0.3 \mathrm{a}$ & $72.2 \pm 0.2 \mathrm{~b}$ & $98.0 \pm 0.6 \mathrm{a}$ & $61.1 \pm 0.2 \mathrm{~b}$ \\
Ce-GMFX 1000 & $60.0 \pm 0.2 \mathrm{bc}$ & $60.0 \pm 0.3 \mathrm{bc}$ & $91.0 \pm 0.0 \mathrm{ab}$ & $41.1 \pm 0.1 \mathrm{c}$ \\
Ce-GMFX 100 & $50.0 \pm 0.2 \mathrm{c}$ & $42.2 \pm 0.1 \mathrm{~d}$ & $92.0 \pm 0.0 \mathrm{ab}$ & $30.0 \pm 0.1 \mathrm{~d}$ \\
Ampicillin 100 $\mu \mathrm{g} / \mathrm{mL}$ & $80.0 \pm 0.3 \mathrm{a}$ & $74.4 \pm 0.3 \mathrm{ab}$ & $98.0 \pm 0.5 \mathrm{a}$ & $32.2 \pm 0.1 \mathrm{~cd}$ \\
Streptomycin 50 $\mu \mathrm{g} / \mathrm{mL}$ & $51.1 \pm 0.1 \mathrm{c}$ & $55.6 \pm 0.1 \mathrm{bc}$ & $96.0 \pm 0.7 \mathrm{a}$ & $53.3 \pm 0.1 \mathrm{bc}$ \\
Kanamycin 50 $\mu \mathrm{gg} / \mathrm{mL}$ & $68.9 \pm 0.2 \mathrm{~b}$ & $71.1 \pm 0.2 \mathrm{~b}$ & $98.0 \pm 0.4 \mathrm{a}$ & $57.8 \pm 0.1 \mathrm{bc}$ \\
Cephaloxacin 30 $\mu \mathrm{g} / \mathrm{mL}$ & $53.3 \pm 0.2 \mathrm{c}$ & $60.0 \pm 0.2 \mathrm{bc}$ & $93.0 \pm 0.9 \mathrm{a}$ & $84.0 \pm 0.14 \mathrm{a}$ \\
Control KB & $0.0 \pm 0.0 \mathrm{~d}$ & $0.0 \pm 0.0 \mathrm{e}$ & $0.0 \pm 0.0 \mathrm{c}$ & $0.00 \pm 0.0 \mathrm{e}$ \\
\hline
\end{tabular}

Where: GMFX: gemifloxacin; Sn: Tin; Zn: Zinc; Ce: Cerium; KB: King's B media. Values are recorded as the mean of bacterial inhibition percentage $(\%)$ from three replicates \pm SDs. Values followed by the different letter in each vertical column for each bacterium are significantly different according to Tukey post hoc test at $p<0.05$.

In case of the antibacterial activity against $C$. michiganensis, the obtained results showed that GMFX and all its metal complexes inhibited its growth completely at all tested concentrations. In case of X. campestris and B. megaterium, the GMFX and all its metal complexes at 10,000 ppm showed the highest significant activity compared to all other treatments. The Ce(III)-GMFX complex at $100 \mathrm{ppm}$ showed the lowest significant activity. The potential antibacterial efficacy of the tested ligand and its metal complexes is thought to depend on the specific toxicity of the studied metals. The low activity observed against E. coli, especially at low concentrations, could be due to the presence of lipopolysaccharides in the outer membrane of the $G$-ve bacteria, which make them inherently resistant 
to external agents. Cole et al. [36] have reported that the differences among G-ve and G+ve bacteria regarding the bactericidal effect are due to the structure of their cell walls, where the $\mathrm{G}$-ve bacteria have a more complex cell wall composed of a thin peptidoglycan layer and an outer membrane containing lipopolysaccharides, whereas G+ve bacteria are protected by a wall predominantly composed by one type of macromolecule (pepidoglycan). The obtained results are in agreement with Sadeek et al. [37] who concluded that there is a significant increase in antibacterial activity of metal complexes compared to uncomplexed ligand.

\subsubsection{Antifungal Activity}

Results of the in vitro antifungal activity testing of the studied ligand GMFX and its metal complexes against $R$. solani and B. cinerea showed that GMFX at 500 and 1000 ppm demonstrated the highest significant activity compared either to all other treatments or the two tested synthetic fungicides azoxystrobin and cycloheximide (Table 6). On the other hand, when the fungicidal activity against S. sclerotiorum was tested, the obtained results showed that azoxystrobin has significantly higher activity than GMFX. There were no significant differences between the Zn(II) and Ce(III) complexes. In the case of antifungal activity against $A$. niger, GMFX exhibited the highest significant activity at all tested concentrations and was similar to the $\mathrm{Zn}$ (II) complex and azoxystrobin. Regarding the activity against P. digitatum, GMFX at 1000 ppm and its Zn(II) complex had the highest significant activity, which was similar to both tested synthetic fungicides, and were followed by all other metal complexes.

Table 6. Antifungal activity of GMFX and its metal complexes.

\begin{tabular}{|c|c|c|c|c|c|c|}
\hline & \multirow[b]{2}{*}{ Conc. $\mu \mathrm{g} / \mathrm{mL}$} & \multicolumn{5}{|c|}{ Fungal Mycelium Growth Inhibition \% } \\
\hline & & R. solani & S. sclerotiorum & A. niger & B. cinerea & P. digitatum \\
\hline \multirow{2}{*}{ GMFX } & 1000 & $78.1 \pm 0.22 \mathrm{a}$ & $71.9 \pm 0.04 \mathrm{ab}$ & $69.0 \pm 0.13 a$ & $91.9 \pm 0.13 a$ & $95.3 \pm 0.11 \mathrm{a}$ \\
\hline & 250 & $50.0 \pm 0.0 \mathrm{c}$ & $0.0 \pm 0.0 \mathrm{~d}$ & $45.0 \pm 0.36 c$ & $60.6 \pm 0.13 b$ & $76.3 \pm 0.09 b$ \\
\hline Sn-GMFX & 1000 & $28.1 \pm 0.22 \mathrm{~d}$ & $6.3 \pm 0.45 \mathrm{~cd}$ & $56.9 \pm 0.09 b$ & $51.3 \pm 0.09 c$ & $76.3 \pm 0.09 b$ \\
\hline \multirow{3}{*}{ Zn-GMFX } & 1000 & $15.6 \pm 0.22 \mathrm{de}$ & $26.9 \pm 0.31 b$ & $65.6 \pm 0.09 \mathrm{ab}$ & $51.3 \pm 0.09 c$ & $90.6 \pm 0.13 a$ \\
\hline & 500 & $7.5 \pm 0.09 \mathrm{e}$ & $18.8 \pm 1.34 \mathrm{bc}$ & $64.4 \pm 0.09 \mathrm{ab}$ & $45.0 \pm 0.09 \mathrm{~cd}$ & $75.0 \pm 0.18 b$ \\
\hline & 250 & $0.0 \pm 0.0 f$ & $11.3 \pm 0.18 c$ & $58.8 \pm 0.36 \mathrm{~b}$ & $37.5 \pm 0.0 \mathrm{~d}$ & $64.4 \pm 0.13 b c$ \\
\hline \multirow[b]{2}{*}{ Ce-GMFX } & 1000 & $43.1 \pm 0.3 \mathrm{~cd} 1$ & $21.9 \pm 0.67 b$ & $64.4 \pm 0.09 \mathrm{ab}$ & $50.0 \pm 0.0 c$ & $71.3 \pm 0.09 b$ \\
\hline & 500 & $18.1 \pm 0.13 d$ & $12.5 \pm 0.89 c$ & $63.8 \pm 0.18 \mathrm{ab}$ & $37.5 \pm 0.0 \mathrm{~d}$ & $65.6 \pm 0.13 b c$ \\
\hline \multicolumn{2}{|c|}{$\begin{array}{c}\text { Azoxystrobin } 1 \mu \mathrm{L} / \mathrm{mL} \\
\text { Cycloheximide } 0.1 \mu \mathrm{L} / \mathrm{mL} \\
\text { PDA ctrl }\end{array}$} & $0.00 \pm 0.0 \mathrm{f}$ & $0.00 \pm 0.0 \mathrm{f}$ & $0.0 \pm 0.0 \mathrm{~d}$ & $0.0 \pm 0.0 \mathrm{~cd}$ & $0.0 \pm 0.0 \mathrm{~d}$ \\
\hline
\end{tabular}

Where: GMFX: gemifloxacin; Sn: Tin; Zn: Zinc; Ce: Cerium; PDA: Potato Dextrose Agar. Values are recorded as the mean of fungal mycelium growth inhibition (\%) from three replicates \pm SDs. Values followed by the different letter in each vertical column for each fungus are significantly different according to Tukey post hoc test at $p<0.05$.

The increased biological activity of metal chelates was explained by the concept of cell permeability and chelation theory. Upon chelation, the polarity of a metal ion is reduced due to the partial sharing of the positive charge with the donor groups of the ligand and as a consequence of overlap with the ligand orbitals. Chelation increases the delocalization of electrons over the whole chelate ring and thus increases the lipophilic nature of the central ion. This increase in lipophilicity enhances the passage of the complex through lipid membranes, facilitating the penetration of cells [38-40].

\subsubsection{Minimum Inhibitory Concentration of Fungicidal Activity}

Minimum inhibitory concentration (MIC) tests were carried out for the most inhibited tested fungi (B. cinerea and $P$. digitatum). The effects of the different concentrations of GMFX and its metal complexes against the above-mentioned fungi were variable. In particular, MIC values in the case 
of B. cinerea were evaluated by $2000 \mathrm{ppm}$ in case of the Ce(III)-GMFX complex and $2100 \mathrm{ppm}$ in the case of the [Zn(II) or Sn(II)]-GMFX complexes and uncomplexed GMFX. Regarding P. digitatum, the MIC values were ordered in the following manner: Sn(II)-GMFX $<$ Ce(III)-GMFX $<$ free GMFX $<$ $\mathrm{Zn}(\mathrm{II})-\mathrm{GMFX}$ where the values were measured as 1400, 2100, 2200, and 2600 ppm, respectively.

\subsubsection{Antioxidant Activity}

We have screened the antioxidant activity of GMFX and its metal complexes to evaluate their electron-donating activity. Results showed the highest significant antioxidant activity for the GMFX-Sn complex $(p<0.05)$ (Figure 4), compared to all other treatments. In particular, the DPPH and ABTS scavenging activity evidenced that Stannum presented the best percentage of antiradical activity. These results are in accordance with Bukhari et al. [41] and Chen et al. [42] who reported that the antioxidant activity of some ligands was increased by the presence of metal, such as Sn(IV).

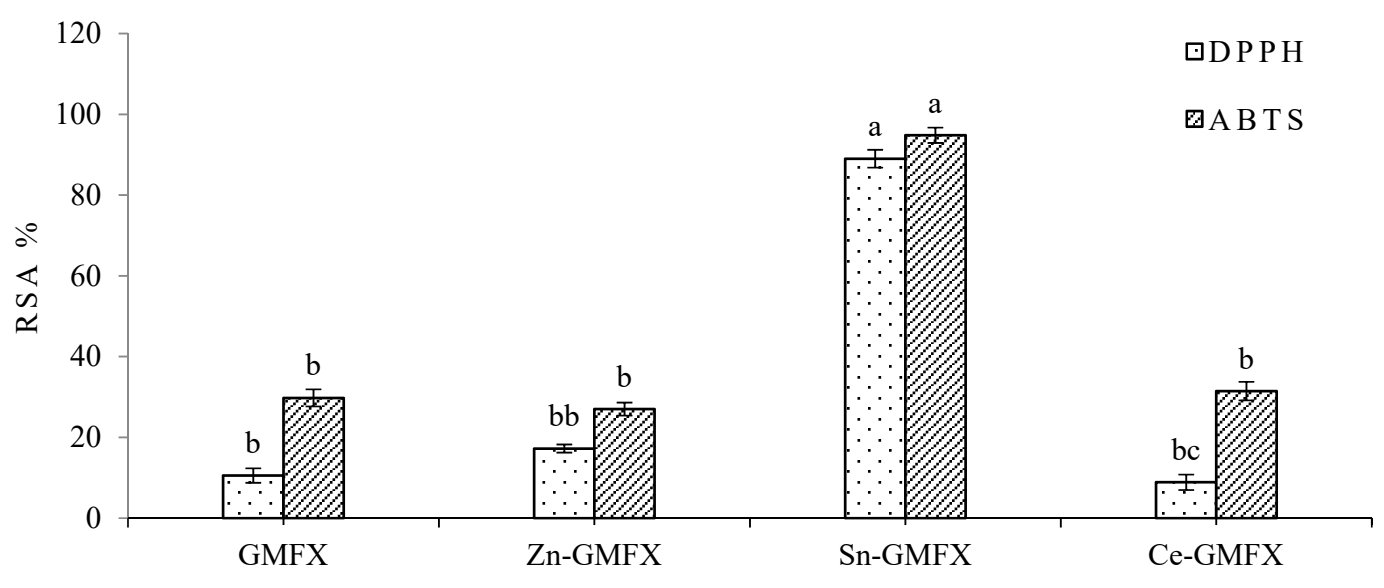

Single ligands and metal complexes

Figure 4. Radical scavenging activity (RSA,\%) of GMFX and its metal complexes derived from 2,2-diphenyl-1-picrylhydrazyl (DPPH) and 2,2'-azinobis (3-ethylbenzthiazoline-6-acid) (ABTS) assays. Bars with different letters for each method indicate means values significantly different at $p<0.05$ according to Tukey post hoc test. Data are expressed as the mean of three replicates \pm SDs.

In any case, the antiradical activity of the GMFX-Sn complex could be due to its hydrogen donating ability, as reported by Corona-Bustamante et al. [43]. A possible exchange mechanism is that the proton from the GMFX ligand is donated and the charge is stabilized inside the entire complex, changing its charge delocalization capacity. The high scavenging activity of the Sn complex may explain its low antimicrobial activity, since the oxygenated compounds may contribute to the attachment to and destruction of the microorganism's cell wall, hence increasing the permeability of cytoplasm fluid and finally leading to cell death.

\section{Materials and Methods}

\subsection{Materials}

All chemicals used for preparation of the complexes were of analytical reagent grade, being commercially available from different sources and used without further purification. Gemifloxacin was purchased from Obour Pharmaceutical Industrial Company (Cairo, Egypt). Glycine, $\mathrm{AgNO}_{3}$, $\mathrm{K}_{2} \mathrm{CrO}_{4}$, and ethanol (99.8\%) were purchased from Fluka, Sigma Aldrich Company (Seelze, Germany). $\mathrm{SnCl}_{2} \cdot 2 \mathrm{H}_{2} \mathrm{O}(98 \%)$ and $\mathrm{ZnCl}_{2}(98 \%)$ were purchased from Carlo Erba company (Milan, Italy). $\mathrm{CeCl}_{3} \cdot 7 \mathrm{H}_{2} \mathrm{O}$ was purchased from Sigma Aldrich Company (Steinheim, Germany). 


\subsection{Synthesis of Mixed Ligand Metal Complexes}

The faint brown solid complex $\left[\mathrm{Sn}(\mathrm{GMFX})(\mathrm{Gly})\left(\mathrm{H}_{2} \mathrm{O}\right)_{2}\right] \mathrm{Cl}$ (Complex 1) was prepared by adding $0.5 \mathrm{mmol}(0.112 \mathrm{~g})$ stannous chloride $\mathrm{SnCl}_{2} \cdot 2 \mathrm{H}_{2} \mathrm{O}$ in $50 \mathrm{~mL}$ ethanol drop-wise to a stirred suspended solution of $0.5 \mathrm{mmol}(0.194 \mathrm{~g})$ GMFX and $0.5 \mathrm{mmol}(0.037 \mathrm{~g})$ glycine(Gly) in $30 \mathrm{~mL}$ ethanol. All reactants were boiled in reflux apparatus in stirred conditions for about $5-6 \mathrm{~h}$ at $100{ }^{\circ} \mathrm{C}$ in water bath. Then, the prepared complex was subjected to the rotary evaporator for $30 \mathrm{~min}$ at $30^{\circ} \mathrm{C}$ and $270 \mathrm{rpm}$ until reach the completely dried complex. The faint yellow and beige solid complexes [ $\left.\mathrm{Zn}(\mathrm{GMFX})(\mathrm{Gly})\left(\mathrm{H}_{2} \mathrm{O}\right)_{2}\right] \mathrm{Cl}_{2} \cdot \mathrm{H}_{2} \mathrm{O}$ (Complex 2) and [Ce(GMFX) $\left.(\mathrm{Gly})\left(\mathrm{H}_{2} \mathrm{O}\right)_{2}\right] \mathrm{Cl}_{2} \cdot \mathrm{H}_{2} \mathrm{O}$ (Complex 3) were prepared in a similar manner by using ethanol as a solvent and $\mathrm{ZnCl}_{2}$ and $\mathrm{CeCl}_{3}$, respectively, in 1:1:1 (GMFX:M:Gly) molar ratio with $0.5 \mathrm{mmol}$ of $\mathrm{ZnCl}_{2}, \mathrm{CeCl}_{3} \cdot 7 \mathrm{H}_{2} \mathrm{O}$, GMFX, and glycine (Gly). We were not able to obtain appropriate monocrystals to perform $\mathrm{X}$-ray diffraction analysis.

Complex (1)

(7-[(4Z)-3-(Aminomethyl)-4-methoxyimino-pyrrolidin-1-yl]-1-cyclopropyl-6-fluoro-4-oxo-1,8naphthyridine-3-carboxylic acid)(aminoethanoic acid)(bihydrate) stannous chloride

Complex (2)

(7-[(4Z)-3-(Aminomethyl)-4-methoxyimino-pyrrolidin-1-yl]-1-cyclopropyl-6-fluoro-4-oxo-1,8naphthyridine-3-carboxylic acid)(aminoethanoic acid)(bihydrate) zinc chloride monohydrate.

Complex (3)

(7-[(4Z)-3-(Aminomethyl)-4-methoxyimino-pyrrolidin-1-yl]-1-cyclopropyl-6-fluoro-4-oxo-1,8naphthyridine-3-carboxylic acid) (aminoethanoic acid) (bihydrate)cerium bicholoride monohydrate.

\subsection{Instruments}

Elemental C, H, N analysis was carried out on a PerkinElmer CHN 2400 (Waltham, MA, USA). The percentage of metal ions was determined by using the atomic absorption method with a PYE-UNICAM SP 1900 spectrometer (Cambridge, UK) fit with the corresponding lamp. IR spectra were recorded from $\mathrm{KBr}$ discs using an FT/IR-460 Plus model Jasco-32 spectrophotometer (Easton, PA, USA) in the range from 4000 to $400 \mathrm{~cm}^{-1}$. ${ }^{1} \mathrm{H}$ NMR spectra were recorded on a Varian $400 \mathrm{NMR}$ spectrometer (Urbana, IL, USA) using $\mathrm{CD}_{3} \mathrm{OD}$ as solvent. Electronic spectra were obtained using T80 UV/Vis spectrometer (Taylors, SC, USA) PG Instruments Ltd. Magnetic susceptibilities of the powdered samples were measured on a Sherwood scientific magnetic balance (Cambridge, UK) using the Gouy method with $\mathrm{Hg}\left[\mathrm{Co}(\mathrm{SCN})_{4}\right]$ as calibrant. Molar conductance of $1 \times 10^{-3} \mathrm{M}$ solutions of ligand and metal complexes in DMF was measured at room temperature using a CONSORT K410 (Turnhout, Belgium). All measurements were carried out at ambient temperature with freshly prepared solutions. Melting points were recorded on a Buchi apparatus.

\subsection{Antimicrobial Investigation}

\subsubsection{Bactericidal Activity Test}

The antibacterial test of the studied ligand and its metal complexes was investigated by the disc diffusion method of Bhunia et al. [20,44,45] against X. campestris, B. megaterium, E. coli, and C. michiganensis with some minor modifications. All strains were listed in National Collection of Plant Pathogenic Bacteria Catalogue (NCPPB) and have been cultivated, lyophilized, and freeze-conserving as pure cultures in the collection of the School of Agricultural, Forestry, Food and Environmental Sciences, University of Basilicata, Potenza, Italy. The bacterial suspension of each strain was prepared in sterile distilled water plus soft agar $(0.7 \%)$ at concentration $10^{8}$ colony form unit (CFU) mL $\mathrm{mL}^{-1}$ (optical density, $\mathrm{OD} \approx 0.2 \mathrm{~nm})$. A mixture of $0.7 \%$ soft agar and bacterial suspension $(9: 1 v / v)$ was prepared and $4 \mathrm{~mL}$ of this suspension was poured into each $10 \mathrm{~mL} \mathrm{~KB}$ Petri dish $90 \mathrm{~mm}$ in diameter. Blank Discs (6 mm)-OXOID (Milan, Italy) were placed over KB-plate surfaces after complete solidification and $20 \mu \mathrm{L}$ aliquots from each ligand and metal complexes at the following concentrations (1:5) 5000, 250, and $62.5 \mathrm{ppm}$. 


\subsubsection{Fungicidal Activity Test}

The antifungal screening was evaluated against five phytopathogenic fungi: $R$. solani, S. sclerotiorum, A. niger, B. cinerea, and P. digitatum. The tested fungi were previously identified by classical and molecular methods and stored in the mycotheca of School of Agricultural, Forestry, Food and Environmental Sciences, University of Basilicata, Potenza, Italy with the following collection numbers: R. solani 1312; S. sclerotiorum 593; A. niger 1008; B. cinerea 479, and P. digitatum 1395. Different concentrations of each treatment at 1000,500, and $250 \mathrm{ppm}$ was prepared in potato dextrose agar (PDA). Fourteen $\mathrm{mL}$ aliquots of previous prepared media supplemented with each treatment was poured into Petri dishes. After the complete dry off of the agar surface under laminar flow, $0.5 \mathrm{~cm}$ diameter of fungal disks square cut off from $96 \mathrm{~h}$ fresh cultures were singularly inoculated in the center of each Petri dish prepared as above. All plates were incubated at $24 \pm 2{ }^{\circ} \mathrm{C}$ for 4 days under dark conditions. The diameter of fungal mycelium growth measured in $\mathrm{mm}$. Petri dishes containing only PDA were also inoculated with fungal disks of the same fungi and used as a control. Each treatment was carried out in triplicate. The fungitoxicity was expressed as growth inhibition percentage (GIP) and calculated according to the formula of Zygadlo et al. [46] (Equation (1)), herein reported. Compared to synthetic fungicide azoxystrobin $1 \mu \mathrm{L} \mathrm{mL}^{-1}$ and cycloheximide $0.1 \mu \mathrm{g} \mathrm{mL}{ }^{-1}$ to PDA nutrient medium:

$$
\operatorname{GIP}(\%)=100 \times(\mathrm{GC}-\mathrm{GT}) / \mathrm{GC},
$$

where: GC = average diameter of fungus colony grown on PDA alone (control); GT = average diameter of fungus colony grown on PDA containing each treatment.

\subsubsection{Determination of Minimum Inhibitory Concentration (96-Well Microplate Method)}

The MIC was considered as the fungicidal effect of each treatment, defined as the lowest concentration of each ligand and metal complexes that definitely inhibits the fungal growth. MIC was determined on 96-well culture plates by a micro-dilution method following the technical procedures of Lehtinen et al. [47]. Spore formation was ascertained after nine days incubation under a light microscope (Axioskop, ZEISS, West Germany). The stock solution of each treatment was prepared in Potato Dextrose Broth (PDB) at 1000, 1200, 1400, 1600, 1800, 2000, 2200, 2400, 2600, 2800, and $3000 \mu \mathrm{g} \mathrm{mL}{ }^{-1}$. The absorbance of fungal growth was read at $\lambda=450 \mathrm{~nm}$ using the Elisa Microplate reader instrument (DAS s.r.l., Rome, Italy). All samples were tested in triplicate.

\subsubsection{Antioxidant Activity}

In the present study, two tests were performed (ABTS and DPPH) following the methodological procedures of the basic principles of Martysiak-Żurowska and Wenta [48], as follows. In these trials, the above mentioned two assays were carried out to determine the radical scavenging activity (RSA\%) of the studied ligand and its metal complexes at $100 \%$ utilizing the following formula:

$$
\text { Radical Scavenging Activity }(\mathrm{RSA} \%)=\left(1-\mathrm{A}_{\mathrm{t}} / \mathrm{A}_{\mathrm{c}}\right) \times 100 \% \text {; }
$$

where $A_{t}$ is the absorbance of sample and $A_{c}$ is the absorbance of colorimetric radical substance without sample.

\section{DPPH: 2,2-diphenyl-1-picrylhydrazyl Assay}

The DPPH method is considered one of the most useful techniques for measuring the antiradical activity of a compound and it depends on the use of the stable free radical DPPH. The electronic delocalization of this radical is responsible for its characteristic deep violet color and hence the compounds which will be able to donate a hydrogen atom will convert the DPPH radical into its reduced form (neutral stable molecule) and then the color switch from deep violet to pale yellow [49,50]. 
Stock radical solution (DPPH solution) was prepared by dissolving $20 \mathrm{mg}$ of DPPH in $15 \mathrm{~mL}$ of ethanol. Thereafter, $1 \mathrm{~mL}$ of DPPH solution was diluted with $29 \mathrm{~mL}$ of ethanol.

Test procedures: $50 \mu \mathrm{L}$ was diluted at (1:20) using $950 \mu \mathrm{L}$ of DPPH solution and was incubated at darkness for $30 \mathrm{~min}$ at room temperature. Later on, all samples were centrifuged at $8000 \mathrm{rpm}$ for $5 \mathrm{~min}$ and the absorbance was measured at $515 \mathrm{~nm}$ in triplicate using a UV-Vis spectrophotometer (LKB Biochrom 4050 Ultrospec II, Arizona, USA) considering the value of the reference sample (ethanol). The stock solution of DPPH was prepared fresh and all determinations were carried out in triplicate.

ABTS: 2,2'-azinobis (3-ethylbenzthiazoline-6-acid) Assay

The ABTS method is considered the most sensitive method and is characterized by higher repeatability for observing the kinetics of specific enzymes. The detectability and sensitivity of ABTS are higher than the DPPH assay.

Stock radical solution. ABTS solution was prepared by dissolving $38 \mathrm{mg}$ of ABTS in $10 \mathrm{~mL}$ of a aqueous sodium persulphate solution $(2.45 \mathrm{mM})$. and the solution was conserved in darkness for $16 \mathrm{~h}$ at room temperature. Then, $1 \mathrm{~mL}$ of stock $\mathrm{ABTS}^{\bullet+}$ solution was diluted with $29 \mathrm{~mL}$ of ethanol.

Test procedures: $20 \mu \mathrm{L}$ of each studied ligand and the metal complexes was diluted at (1:50) using $980 \mu \mathrm{L}$ of radical $\mathrm{ABTS}^{\bullet+}$ solution and was incubated after that in darkness at room temperature for $2 \mathrm{~h}$. All samples were centrifuged at $8000 \mathrm{rpm}$ for $5 \mathrm{~min}$ and the absorbance was measured at $734 \mathrm{~nm}$ by using UV-Vis spectrophotometer (LKB Biochrom 4050 Ultrospec II) considering the value of reference sample (ethanol). The stock solution of ABTS was prepared fresh and all determinations were carried out in triplicate.

\subsection{Statistical Analysis}

The outcomes of the biological tests were statistically analyzed using statistical package for the social sciences (SPSS) (version 13.0. Prentice Hall, Chicago, IL, USA, 2004). Experimental data were expressed as mean \pm SD and comparisons were employed by Tukey post-hoc test for detecting any significance differences among different treatments at $p<0.05$.

Author Contributions: S.H.S., H.S.E. and S.A.S. designed the research study and wrote the manuscript; S.H.S. and H.S.E. performed the IR and NMR tests; S.H.S. and S.A.S. carried out the elemental analysis and UV-Vis test; H.S.E. and I.C. carried out the antimicrobial and antioxidant tests and discussed their results; S.H.S. and S.A.S. discussed the results of NMR and UV-Vis analysis; All coauthors revised scientifically the whole manuscript.

Acknowledgments: The authors would like to acknowledge Licia Viggiani and Agostino Galasso, Department of Chemistry, University of Basilicata, Italy for their assistance in NMR and IR analysis.

Conflicts of Interest: The authors declare no conflicts of interest.

\section{References}

1. Psomas, G.; Tarushi, A.; Efthimiadou, E.K. Synthesis, characterization and DNA-binding of the mononuclear dioxouranium(VI) complex with ciprofloxacin. Polyhedron 2008, 27, 133-138. [CrossRef]

2. Lesher, G.Y.; Froelich, E.J.; Gruett, M.D.; Bailey, J.H.; Brundage, R.P. 1,8-Naphthyridine derivatives: A new class of chemotherapeutic agents. J. Med. Pharm. Chem. 1962, 5, 1063-1065. [CrossRef]

3. Nelson, J.M.; Chiller, T.M.; Powers, J.H.; Angulo, F.J. Fluoroquinolone-resistant Campylobacter species and the withdrawal of fluoroquinolones from use in poultry: A public health success story. Clin. Infect. Dis. 2007, 447, 977-980. [CrossRef] [PubMed]

4. Turel, I. The interactions of metal ions with quinolone antibacterial agents. Coord. Chem. Rev. 2002, 232, 27-47. [CrossRef]

5. Andriole, V.T. (Ed.) The Quinolones, 3rd ed.; Chapter 16 the Quinolones: Prospects; Elsevier: New York, NY, USA, 2000; pp. 477-495, ISBN 978-0-12-059517-4.

6. Kuhlmann, J.; Schaefer, H.G.; Beermann, D. Quinolone Antibacterials; Chapter 11 Clinical Pharmacology; Kuhlmann, J., Dalhoff, A., Zeile, A.J., Eds.; Springer: Berlin, Germany, 1998; Volume 127, pp. 339-406. 
7. Johnson, D.M.; Jones, R.N.; Erwin, M.E. Anti-streptococcal activity of SB-265805 (LB20304), a novel fluoronaphthyridone, compared with five other compounds, including quality control guidelines. Diagn. Microbiol. Infect. Dis. 1999, 33, 87-91. [CrossRef]

8. Grossman, R.; Rotschafer, J.; Tan, J. Antimicrobial treatment of lower respiratory tract infections in the hospital setting. Am. J. Med. 2005, 118, 29-38. [CrossRef] [PubMed]

9. Kan, Y.K.; Hsu, Y.L.; Chen, Y.H.; Chen, T.C.; Wang, J.Y.; Kuo, P.L. Gemifloxacin, a fluoroquinolone antimicrobial drug, inhibits migration and invasion of human colon cancer cells. BioMed Res. Int. 2013, 2013, 1-11. [CrossRef] [PubMed]

10. Patel, R.N.; Singh, N.; Shukla, K.K.; Gundla, V.L.N.; Chauhan, U.K. Synthesis, characterization and biological activity of ternary copper(II) complexes containing polypyridyl ligands. Spectrochim. Acta Part A 2006, 63, 21-26. [CrossRef] [PubMed]

11. Viossat, B.; Daran, J.; Savouret, G.; Morgant, G.; Greenaway, F.T.; Dung, N.; Pham-Tran, V.A.; Sorenson, J.R.J. Low-temperature $(180 \mathrm{~K})$ crystal structure, electron paramagnetic resonance spectroscopy, and propitious anticonvulsant activities of CuII2(aspirinate)4(DMF)2 and other CuII2(aspirinate) 4 chelates. J. Inorg. Biochem. 2003, 96, 375-385. [CrossRef]

12. Dimiza, F.; Papadopoulos, A.N.; Tangoulis, V.; Psycharis, V.; Raptopoulou, C.P.; Kessissoglou, D.P.; Psomas, G. Biological evaluation of non-steroidal anti-inflammatory drugs-cobalt(II) complexes. Dalton Trans. 2010, 39, 4517-4528. [CrossRef] [PubMed]

13. Turel, I.; Golobic, A.; Klavzar, A.; Pihlar, B.; Buglyo, P.; Tolis, E.; Rehder, D.; Sepcic, K. Interactions of oxovanadium(IV) and the quinolone family member-Ciprofloxacin. J. Inorg. Biochem. 2003, 95, 199-207. [CrossRef]

14. Lopez-Gresa, M.P.; Ortiz, R.; Perello, L.; Latorre, J.; Liu-Gonzalez, M.; Garcia-Granda, S.; Perez-Priede, M.; Canton, E. Interactions of metal ions with two quinolone antimicrobial agents (cinoxacin and ciprofloxacin). Spectroscopic and X-ray structural characterization. Antibacterial studies. J. Inorg. Biochem. 2002, 92, 65-74. [CrossRef]

15. Efthimiadou, E.K.; Katsarou, M.E.; Karaliota, A.; Psomas, G. Copper(II) complexes with sparfloxacin and nitrogen-donor heterocyclic ligands: Structure-activity relationship. J. Inorg. Biochem. 2008, 102, 910-920. [CrossRef] [PubMed]

16. Efthimiadou, E.K.; Thomadaki, H.; Sanakis, Y.; Raptopoulou, C.P.; Katsaros, N.; Scorilas, A.; Karaliota, A.; Psomas, G. Structure and biological properties of the copper(II) complex with the quinolone antibacterial drug N-propyl-norfloxacin and 2,2'-bipyridine. J. Inorg. Biochem. 2007, 101, 64-73. [CrossRef] [PubMed]

17. Katsarou, M.E.; Efthimiadou, E.K.; Psomas, G.; Karaliota, A.; Vourloumis, D. Novel copper(II) complex of $\mathrm{N}$-propyl-norfloxacin and 1,10-phenanthroline with enhanced antileukemic and DNA nuclease activities. J. Med. Chem. 2008, 51, 470-478. [CrossRef] [PubMed]

18. Mohamed, G.G.; Abd El-Halim, H.F.; El-Dessouky, M.M.I.; Mahmoud, W.H. Synthesis and characterization of mixed ligand complexes of lomefloxacin drug and glycine with transition metals. Antibacterial, antifungal and cytotoxicity studies. J. Mol. Struct. 2011, 999, 29-38. [CrossRef]

19. Geary, W.J. The use of conductivity measurements in organic solvents for the characterisation of coordination compounds. Coord. Chem. Rev. 1971, 7, 81-122. [CrossRef]

20. Abu-Dief, A.M.; Nassr, L.A.E. Tailoring, physicochemical characterization, antibacterial and DNA binding mode studies of $\mathrm{Cu}(\mathrm{II})$ Schiff bases amino acid bioactive agents incorporating 5-bromo-2-hydroxybenzaldehyde. J. Iran. Chem. Soc. 2015, 12, 943-955. [CrossRef]

21. Uivarosi, V. Metal Complexes of Quinolone Antibiotics and Their Applications: An Update. Molecules 2013, 18, 11153-11197. [CrossRef] [PubMed]

22. Bhunia, A.K.; Johnson, M.C.; Ray, B. Purification, characterization and microbial spectrum of a bacteriocin produced byPediococcus acidilactici. J. Appl. Bacteriol. 1988, 65, 261-268. [CrossRef] [PubMed]

23. Nakamoto, L. Infrared spectra of inorganic and coordination compounds. J. Chem. Educ. 1963, 40, 501.

24. Sadeek, S.A.; EL-Shwiniy, W.H.; El-Attar, M.S. Synthesis, characterization and antimicrobial investigation of some moxifloxacin metal complexes. Spectrochim. Acta A Mol. Biomol. Spectrosc. 2011, 84, 99-110. [CrossRef] [PubMed]

25. Sadeek, S.A.; EL-Shwiniy, W.H. Metal complexes of the fourth generation quinolone antimicrobial drug gatifloxacin: Synthesis, structure and biological evaluation. J. Mol. Struct. 2010, 977, 243-253. [CrossRef] 
26. Macias, B.; Martinez, M.; Sanchez, A.; Dominguez, A. A physico-chemical study of the interaction of ciprofloxacin and ofloxacin with polivalent cations. Int. J. Pharm. 1994, 106, 229-235.

27. Turel, I.; Bukovec, N.; Farkas, E. Complex formation between some metals and a quinolone family member (ciprofloxacin). Polyhedron 1996, 15, 269-275. [CrossRef]

28. Abdel-Rahman, L.H.; Abu-Dief, A.M.; Adam, M.S.; Hamdan, S.K. Some New Nano-sized Mononuclear $\mathrm{Cu}(\mathrm{II})$ Schiff Base Complexes: Design, Characterization, Molecular Modeling and Catalytic Potentials in Benzyl Alcohol Oxidation. Catal. Lett. 2016, 146, 1373-1396. [CrossRef]

29. Abdel-Rahman, L.H.; Abu-Dief, A.M.; Moustafa, H.; Hamdan, S.K. Ni(II) and Cu(II) complexes with ONNO asymmetric tetradentate Schiff base ligand: Synthesis, spectroscopic characterization, theoretical calculations, DNA interaction and antimicrobial studies. Appl. Organometal. Chem. 2017, 31, e3555. [CrossRef]

30. Petrenko, V.I.; Radysh, H.V. Treatment of drug resistant destructive pulmonary tuberculosis: Gemifloxacin and other fluoroquinolones clinical efficiency and tolerance at the end of initial phase of treatment. Likar. Sprav. 2013, 8, 55-63.

31. Kasselouri, S.; Hadjiliadis, N. Interaction of cis-Pd(guo $)_{2} \mathrm{Cl}_{2}$ with amino acids. Inorg. Chim. Acta 1990, 168, 15-26. [CrossRef]

32. Bellamy, L.J. The Infrared Spectra of Complex Molecules, 3rd ed.; Chapman and Hall: London, UK, 1975.

33. Abdel-Rahman, L.H.; El-Khatib, R.M.; Nassr, L.A.E.; Abu-Dief, A.M.; Lashin, F.E. Design, characterization, teratogenicity testing, antibacterial, antifungal and DNA interaction of few high spin Fe(II) Schiff base amino acid complexes. Spectrochim. Acta Part A 2013, 111, 266-276. [CrossRef] [PubMed]

34. Abdel-Rahman, L.H.; Abu-Dief, A.M.; Aboelez, M.O.; Abdel-Mawgoud, A.H. DNA interaction, antimicrobial, anticancer activities and molecular docking study of some new $\mathrm{VO}(\mathrm{II}), \mathrm{Cr}(\mathrm{III}), \mathrm{Mn}(\mathrm{II})$ and $\mathrm{Ni}(\mathrm{II})$ mononuclear chelates encompassing quaridentate imine ligand. J. Photochem. Photobiol. B 2017, 170, 271-285. [CrossRef] [PubMed]

35. Macias, B.; Villa, M.V.; Rubio, I.; Castineiras, A.; Borras, J. Complexes of Ni(II) and Cu(II) with ofloxacin Crystal structure of a new $\mathrm{Cu}(\mathrm{II})$ ofloxacin complex. J. Inorg. Biochem. 2001, 84, 163-170. [CrossRef]

36. Cole, A.; Goodfield, J.; Williams, D.R.; Midley, J.M. The complexation of transition series metal ions by nalidixic acid. Inorg. Chim. Acta 1984, 92, 91-97. [CrossRef]

37. Sadeek, A.S.; Abd El-Hamid, S.M.; El-Aasser, M.M. Synthesis, characterization, antimicrobial and cytotoxicity studies of some transition metal complexes with gemifloxacin. Monatsh Chem. 2015, 146, 1967-1982. [CrossRef]

38. Tumer, M.; Koksal, H.; Sener, M.K.; Serin, S. Antimicrobial activity studies of the binuclear metal complexes derived from tridentate Schiff base ligands. Transit. Met. Chem. 1999, 24, 414-420. [CrossRef]

39. Imran, M.; Iqbal, J.; Iqbal, S.; Ijaz, N. In Vitro Antibacterial studies of ciprofloxacin-imines and their complexes with $\mathrm{Cu}(\mathrm{II}), \mathrm{Ni}(\mathrm{II}), \mathrm{Co}(\mathrm{II})$, and Zn(II). Turk. J. Biol. 2007, 31, 67-72.

40. Patel, N.H.; Parekh, H.M.; Patel, M.N. Synthesis, physicochemical characteristics, and biocidal activity of some transition metal mixed-ligand complexes with bidentate (NO and NN) Schiff bases. J. Pharm. Chem. 2007, 41, 78-81. [CrossRef]

41. Bukhari, S.B.; Memon, S.; Mahroof-Tahir, M.; Bhanger, M.I. Synthesis, characterization and antioxidant activity copper-quercetin complex. Acta Part A Mol. Biomol. Spec. 2009, 71, 1901-1906. [CrossRef] [PubMed]

42. Chen, W.; Sun, S.; Cao, W.; Liang, Y.; Song, J. Antioxidant property of quercetin-Cr(III) complex: The role of Cr(III) ion. J. Mol. Struct. 2009, 918, 194-197. [CrossRef]

43. Corona-Bustamante, A.; Viveros-Paredes, J.M.; Flores-Parra, A.; Peraza-Campos, A.L.; Martínez-Martínez, F.J.; Sumaya-Martínez, M.T.; Ramos-Organillo, Á. Antioxidant activity of Butyl- and Phenylstannoxanes derivedfrom 2-, 3- and 4-Pyridinecarboxylic acids. Molecules 2010, 15, 5445-5459. [CrossRef] [PubMed]

44. Abdel-Rahman, L.H.; El-Khatib, R.M.; Nassr, L.A.E.; Abu-Dief, A.M.; Ismael, M.; Seleem, A.A. Metal based pharmacologically active agents: Synthesis, structural characterization, molecular modeling, CT-DNA binding studies and in vitro antimicrobial screening of iron(II) bromosalicylidene amino acid chelates. Spectrochim. Acta Part A Mol. Biomol. Spectrosc. 2014, 117, 366-378. [CrossRef] [PubMed]

45. Abdel-Rahman, L.H.; Abu-Dief, A.M.; El-Khatib, R.M.; Abdel-Fatah, S.M. Sonochemical synthesis, DNA binding, antimicrobial evaluation and in vitro anticancer activity of three new nano-sized $\mathrm{Cu}(\mathrm{II}), \mathrm{Co}(\mathrm{II})$ and $\mathrm{Ni}(\mathrm{II})$ chelates based on tri-dentate NOO imine ligands as precursors for metal oxides. J. Photochem. Photobiol. B 2016, 162, 298-308. [CrossRef] [PubMed] 
46. Zygadlo, J.A.; Guzman, C.A.; Grosso, N.R. Antifungal properties of the leaf oils of Tagetes minuta L. and Tagetes filifolia Lag. J. Essent. Oil Res. 1994, 6, 617-621. [CrossRef]

47. Lehtinen, J.; Järvinen, S.; Virta, M.; Lilius, E.M. Real-time monitoring of antimicrobial activity with the multiparameter microplate assay. J. Microbiol. Meth. 2006, 66, 381-389. [CrossRef] [PubMed]

48. Martysiak-Żurowska, D.; Wenta, W. Comparison of ABTS and DPPH methods for assessing the total antioxidant capacity of human milk. Acta Sci. Pol. Technol. Aliment. 2012, 11, 83-89. [PubMed]

49. Bafna, A.; Mishra, S. Actividad antioxidante in vitro del extracto de metanol de los rizomas de Curculigo orchioides Gaertn. ARS Pharm. 2005, 46, 125-138.

50. Abdel-Rahman, L.H.; Abu-Dief, A.M.; Newair, E.F.; Hamdan, S.K. Some new nano-sized Cr(III), Fe(II), Co(II), and $\mathrm{Ni}(\mathrm{II})$ complexes incorporating 2-((E)-(pyridine-2-ylimino)methyl)napthalen-1-ol ligand: Structural characterization, electrochemical, antioxidant, antimicrobial, antiviral assessment and DNA interaction. J. Photochem. Photobiol. B Biol. 2016, 160, 18-31. [CrossRef] [PubMed]

(C) 2018 by the authors. Licensee MDPI, Basel, Switzerland. This article is an open access article distributed under the terms and conditions of the Creative Commons Attribution (CC BY) license (http://creativecommons.org/licenses/by/4.0/). 